\title{
Trade in scrap materials: Looking beyond plastics
}

\author{
Henrique Pacini ${ }^{1}$ \\ Jennifer Golbeck ${ }^{2}$
}

\begin{abstract}
Growing evidence about the negative socio-environmental consequences of plastic pollution led to various initiatives for better plastic scrap governance and its trade. At the same time, an examination of recent data shows that plastic scrap represents only a fraction of recyclable materials which are traded internationally and are also subject to similar problems of cross-border environmental governance. A limited analysis comparing plastics, textiles, paper and ferrous metals suggests that ongoing momentum for improvement of plastic scrap governance and circularity should also be framed to consider other types of secondary materiais.
\end{abstract}

Keywords: Scrap materials, trade, resource flows, embedded emissions, circular economy

\section{Introduction}

Global demand for plastics, paper, metals and textiles have seen extraordinary increases over the last decades (Krausmann et al, 2009). The residue streams from those materials are in principle recyclable and can be re-inserted into the economy though secondary material markets (Schrek and Wagner, 2017).

In countries, the management of residue flows is done through a mix of domestic and export strategies, influenced by processing costs, regulatory constraints and industrial capacities (Liu et al, 2018). The dynamics of international trade also play an important role, as trade surpluses in goods markets between Asia and western countries create a net material flow from one region to another. This also has implications for shipping rates, which are cheaper towards regions with export surpluses on goods markets. As a consequence, this dynamic invites scrap exports from developed countries primarily towards Asia (Preston and Lehne, 2017).

Since 2016, a serious trade dispute has emerged between the United States and the European Union, on one side, and scrap-importing regions like China on the other. Based on arguments that the imported scrap materials were not properly sorted and led to environmental pollution, China notified the WTO in 2017 that it would not allow imports of scrap plastics and thirty-one other scrap materials into the country (Katz, 2019). China's case had legal backing in GATT article 20, which foresees the possibility of import restrictions to safeguard public health (GATT, 1994). This led to a global scramble for new recyclers around the world, and the realization that many countries lacked the industrial capacities to economically reprocess their own material flows (Epicenter, 2019; WTO, 2017).

1 - Harvard University, Weatherhead Center for International Affairs. 2 - College of Information Studies, University of Maryland. 
Following the WTO notification, in 2018 the Chinese government imposed an import ban on 24 types of scrap materials, including plastics, as part of an environmental reform movement designed to deal with its growing waste problems (Liu, 2020). By refusing entry to plastic scrap that wasn't $99.5 \%$ pure, imports of that material plummeted by 99 percent as reported by the Chinese Customs. This led to a major global shift in where and how plastic material is processed, prompting increases in recycling costs, burning and landfilling for developed countries such as the United States and the United Kingdom (Waste360, 2019).

Following China's ban, Malaysia became the world's largest importer of plastic scrap. The country, however, announced plans in late 2018 to curb plastic imports until 2023 (CNBC, 2019). Similar restrictions were announced by the Philippines (Nikkei, 2019). While plastics have caught much of the headlines, other scrap materials were traded at higher volumes, values and climate impacts than plastics. This paper frames a comparison of other selected scrap materials, comparing them to scrap plastics in world trade.

\section{Scrap materials and their dimensions}

Taping end-of-life materials for their embodied value conserves part of the economic effort invested into producing them, and reduces the need for further ecosystem subsidies in making new products with virgin materials (lacovidou et. al., 2017). Primary production is often damaging to nature, through $\mathrm{CO} 2$ emissions and various types of pollution, whose consequences grow with time (Rockstrom et. al., 2009; IPCC, 2018; Stahel, 2016; UNCTAD, 2020).

Products in the economy contain both human-made inputs such as intermediary goods and services (e.g., plastics, metals, electronics, labor, knowledge) and inputs from ecosystem services (e.g., clean water and air, nitrogen cycles, pollination). When a product reaches end-of-life, if it leaks into the environment or is landfilled, what is being discarded is not only the human-sourced inputs but also the ecosystem-provided "subsidies" to the production of that particular good. In other words, burying or disposing used things into the environment result in a double loss, for humankind and for nature. A better and circular cross-border material stewardship is being recognized as essential for trade in the future (UNCTAD, 2018).

Significant attention has been devoted to the consequences of plastic waste on the environment, as well as its trade (Eriksen et. al., 2014; Brooks et. al., 2018). At the same time, many other scrap materials are traded internationally, representing a USD 86 billion market in 2019 (ISRI, 2020). Other types of traded scrap materials such as paper, textiles and scrap metals have received far less attention in literature concerning their impacts on nature and society.

While a significant market, scrap materials traded internationally are only a small part of the global secondary materials market. Table 1 presents estimations for the size of traded vs domestic markets for selected scrap materials (plastics, paper, textiles and ferrous metals). 
Table 1. Market estimates for selected scrap materials (2018).

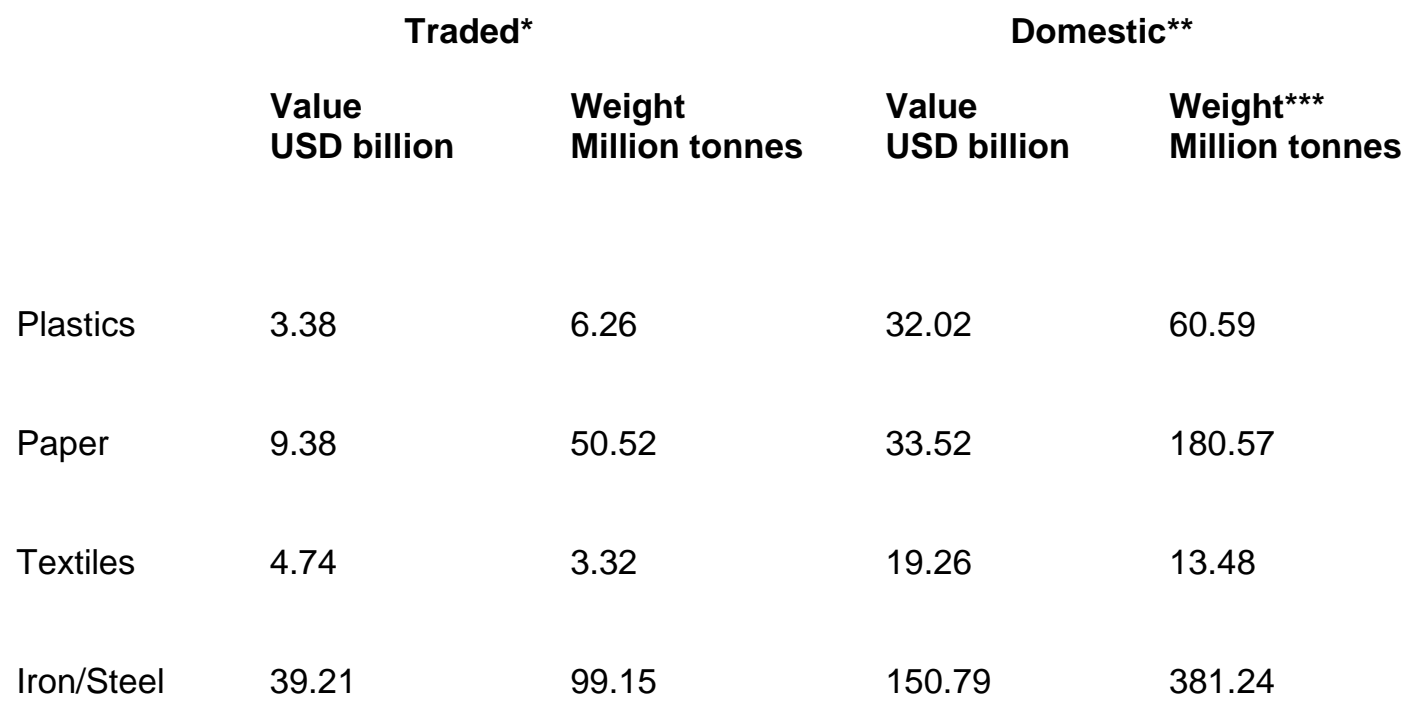

*Based on COMTRADE. Export values for products SITC 579, 2511, 269 and 282. **Adapted from global estimates from Businesswire (2019), Statista (2018), Recycling International (2019) and Recycling International (2018). ${ }^{* * *}$ Considering domestic USD $/ \mathrm{kg}$ being equivalent to traded estimate.

Based on industry estimates and COMTRADE data, Table. 1 suggests that only about $10 \%$ of the global scrap plastics market transits in international trade, with the bulk (90\%) being dealt with at national levels. Other scrap materials such as paper, textiles and iron/steel all show similar figures, with estimated market splits of approximately $20 \%$ being traded and $80 \%$ domestic, based on the estimates and its assumptions. One must notice, however, that global material statistics reported by industry sources are limited at best, given the lack of official statistics in many highgrowth developing countries with high shares of informality (Wilson et. al., 2006).

\subsection{Comparing scrap material trade}

Materials traded internationally on secondary markets differ in their value, volume and pollution impacts. In addition to the well known consequences of plastic pollution on the environment (Liu, 2020; Brooks et. al., 2018), Hasanbeigi and Price (2015) showed comparable impacts from the textile sector. Similarly, the pulp and paper industry has been previously associated with environmental consequences (Ince et. al., 2011). Ferrous metals are also linked to pollution, especially steel alloy scraps sites connected to heavy metal detection in the soil (Sofilic et. al., 2013). Furthermore, while metal recycling is widespread, recycling rates ate only around $20 \%$ in OECD countries, with steel recycling decreasing since 2000 (OECD, 2018). 


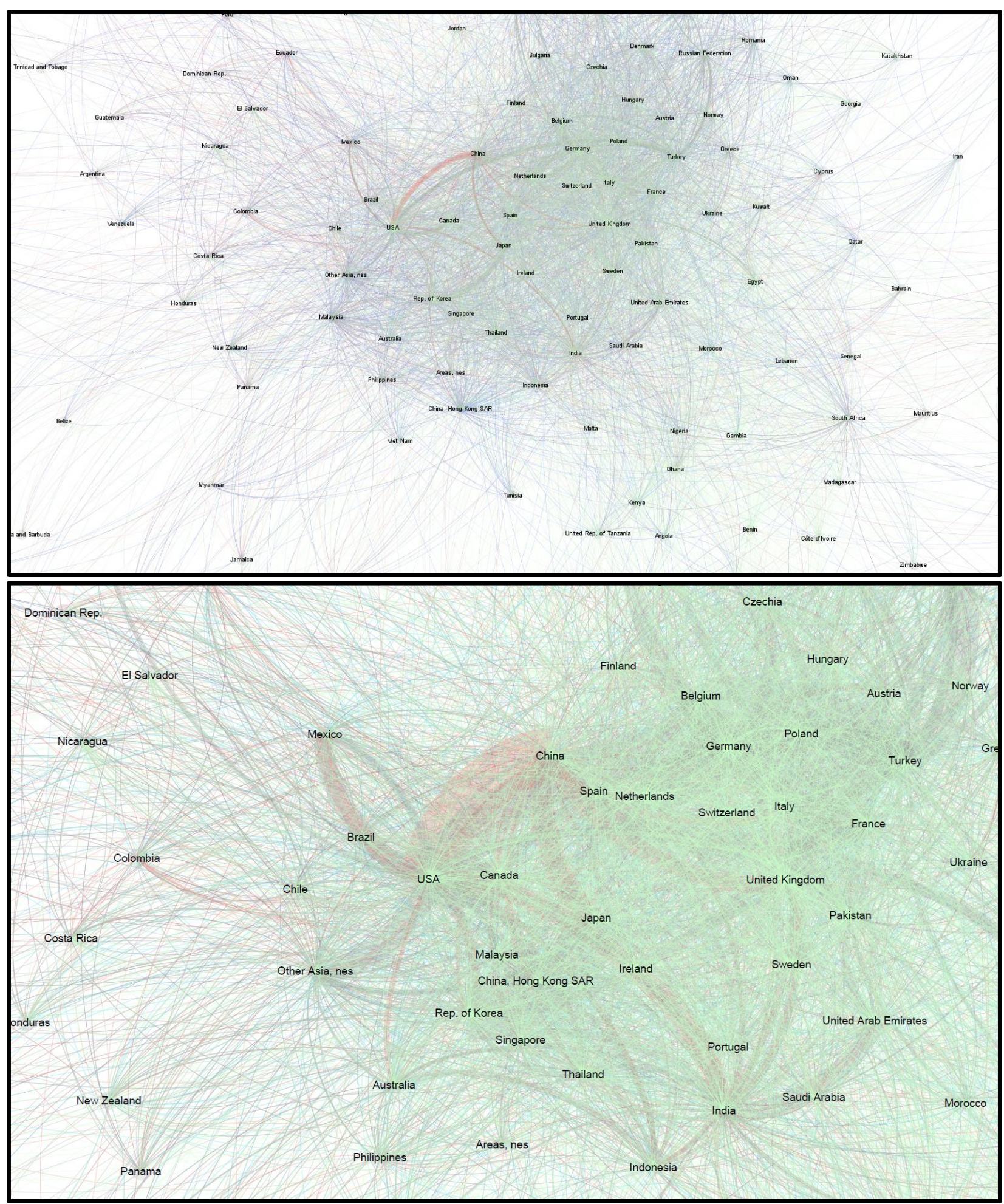

Figure 1. Global scrap trade network for plastics, ferrous metals, textiles and paper.

Source: Prepared by the authors on Gephi, using 2018 data from UN COMTRADE, SITCv4 codes. Width of lines represent volume of trade (weight). Color representation: Green: Textiles (269); Blue: Plastic scrap (579); Grey: Iron/Steel Scrap (282); Red: Paper waste (2511). 
A trade network visualization performed on Gephi can help illustrate some patterns of trade of selected scrap materials in the world. Figure 1 shows the constructed network for selected scrap materials traded in 2018. The arcs in the network visualization indicate the direction of the flow. Arcs move clockwise from the source to the destination. For example, a clockwise arc from the United States to China would indicate trade flowing from the US to China. Based on the network, some insights can be inferred.

The textile network has the largest number of connections, indicating trade in used textiles is done among many countries, highly dispersed and potentially at smaller scales. This can be seen by the high network density observed among European countries. A large participation of east African countries as recipients of used textiles is also noticeable (Katende-Gagezi, 2017). Textiles also represent the highest value, with prices per kilogram of traded material averaging USD $1.13 / \mathrm{kg}$. This is partially due to the material characteristics, as some used garments can be readily resold with little or no repair.

Ferrous metals are traded in larger volumes than textiles and plastics, and highly visible directional flows can be noticed for example from Russia towards Turkey, from Mexico to the United States, and from Australia to Indonesia. Ferrous metals (e.g. iron and steel scrap) have been traded at an average value of USD $0.57 / \mathrm{kg}$. Paper scrap represented the same time the largest weights traded and the lowest values per weight, with an average of USD 0.18/kg in 2018. Large flows of this material took place from the United States to China, Mexico and India respectively. Those flows are arguably linked to single-use packaging in consumption-intensive regions (Pongracz, 2007).

Plastic scrap was also traded broadly among countries in 2018, with material values averaging USD 0.45/kg in 2018, with significant flows towards Asian countries such as Malaysia and Indonesia (CNBC, 2019; Katz, 2019). Figure 2 and Annex 1 further details the values under which scrap materials were traded in 2018 and 2015. 


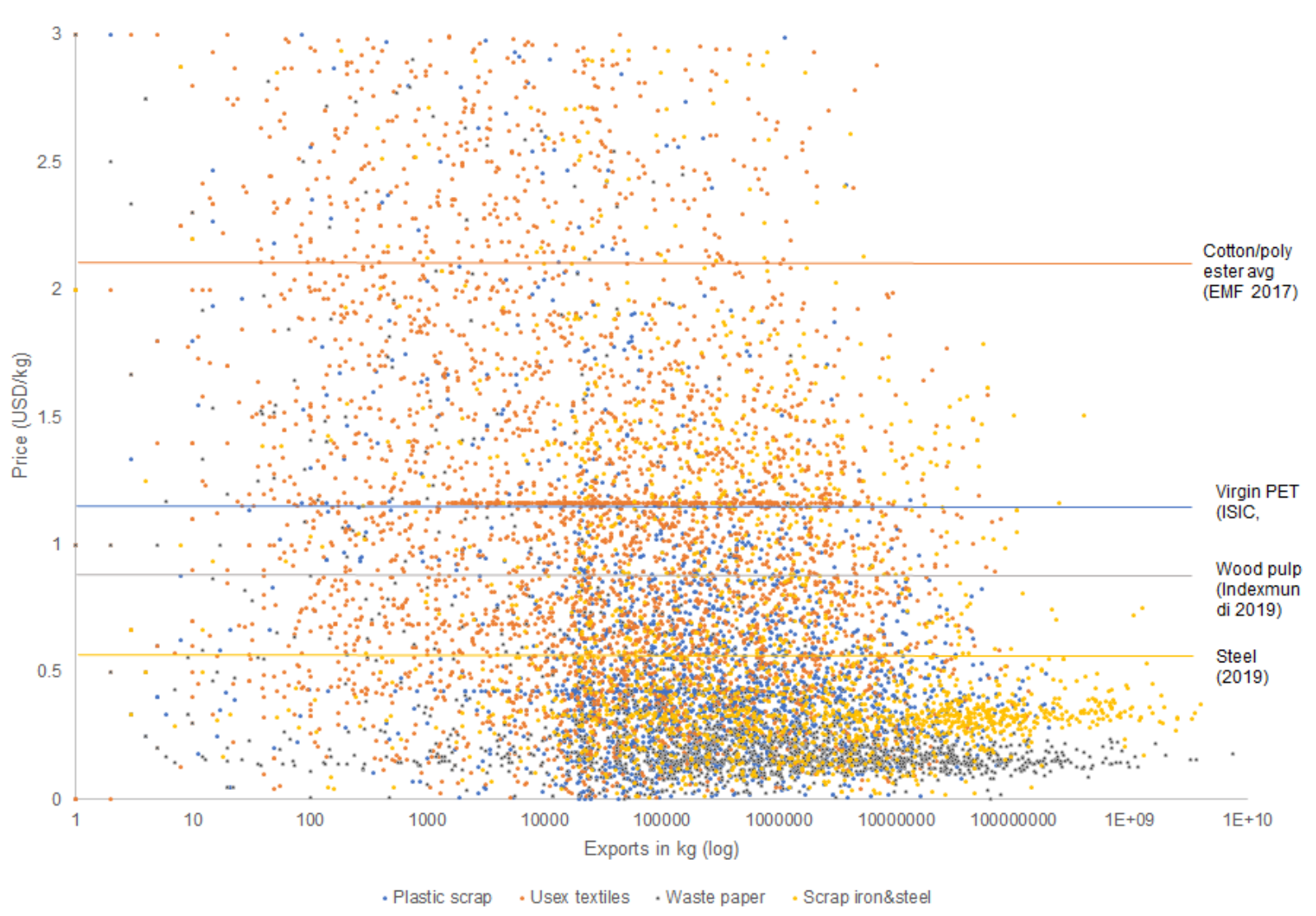

Figure 2. Calculated prices (per kg) of selected scrap materials traded in 2018, compared to primary (e.g. virgin) equivalents. Source: Authors calculations based on COMTRADE data for 2018.

\subsection{Embedded value, embedded footprints}

The commercial flows of scrap materials in world trade can be represented by different metrics. In addition to values traded, information for weight is usually available. Based on this data, estimations can be made for associated environmental impacts, such as water intensity, pollution generated or embedded carbon emissions (Dalin et. al., 2017; SMEP, 2020; Steinberger et. al., 2012; Kissinger et. al., 2013). Understanding the different dimensions of scrap materials trade is important, not only for direct pollution control or governance-building efforts, but also because some materials can have embodied characteristics which are disproportionately larger than others.

Figures 3-5 illustrate trade flows of scrap plastics, paper, ferrous metals and textiles from their major exporters to major importers in 2018. Visualizations are presented for declared values, weight and estimated carbon emissions based on embodied emissions estimates from Kissinger et. al. (2013). Plastics have played an important role in discussions around scrap material governance in recent years. At the same time, the Sankey flow diagrams show that the value, volume (weight) and associated emissions from plastic scrap trade can be far smaller than other scrap materials traded. Plastics and textiles both have comparative small value and tonnage traded when compared to paper and ferrous metal scrap. Yet, when emissions are considered, textiles carry emissions impact that are disproportionately larger than their weight (Fig. 5). 


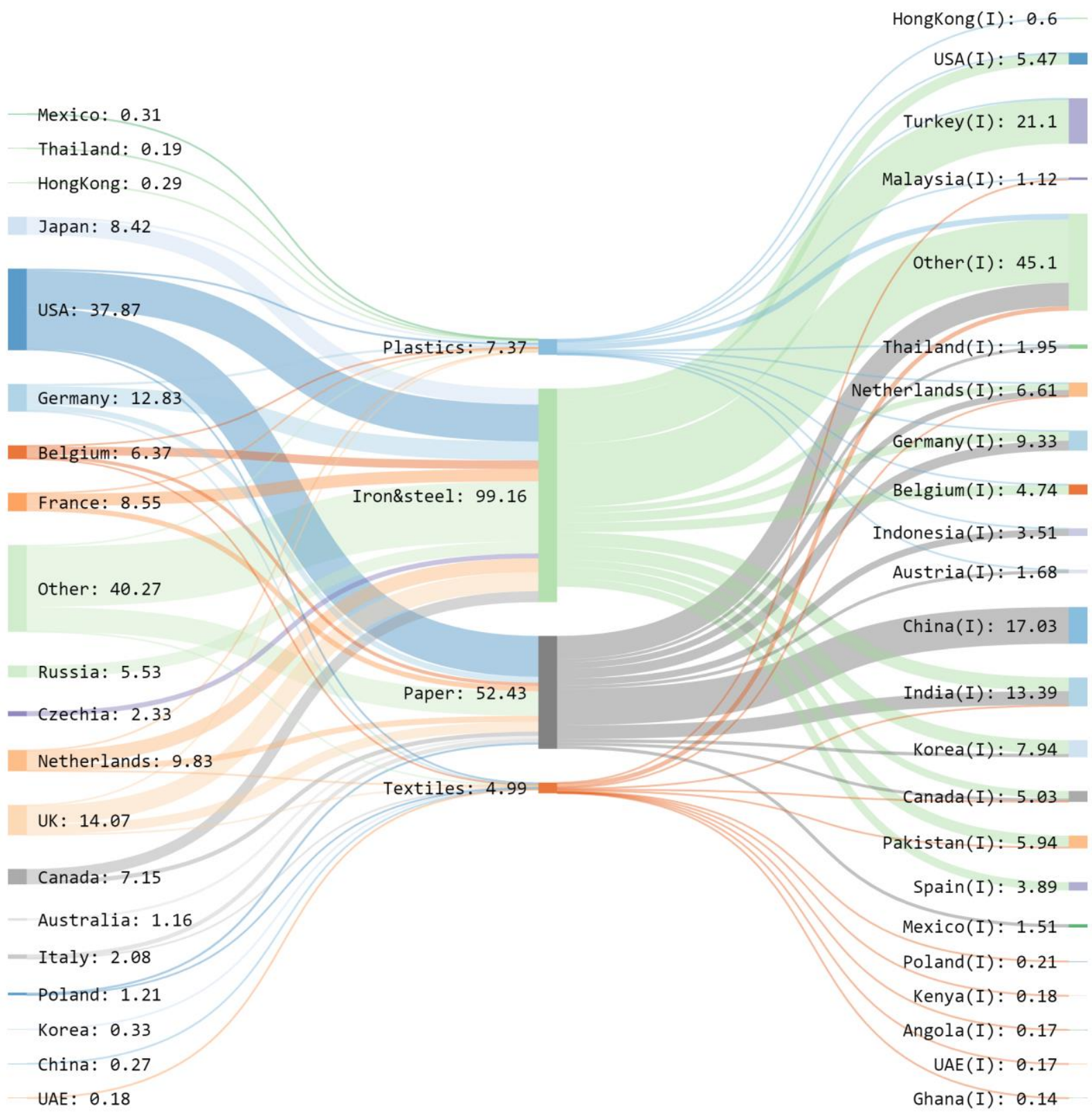

Figure 3. Sources and destinations of selected scrap materials in world trade, in USD billions, 2018. Processed on Sankeymatic, based on COMTRADE SITC v4 data (products 579, 282, 269 and 2511) 


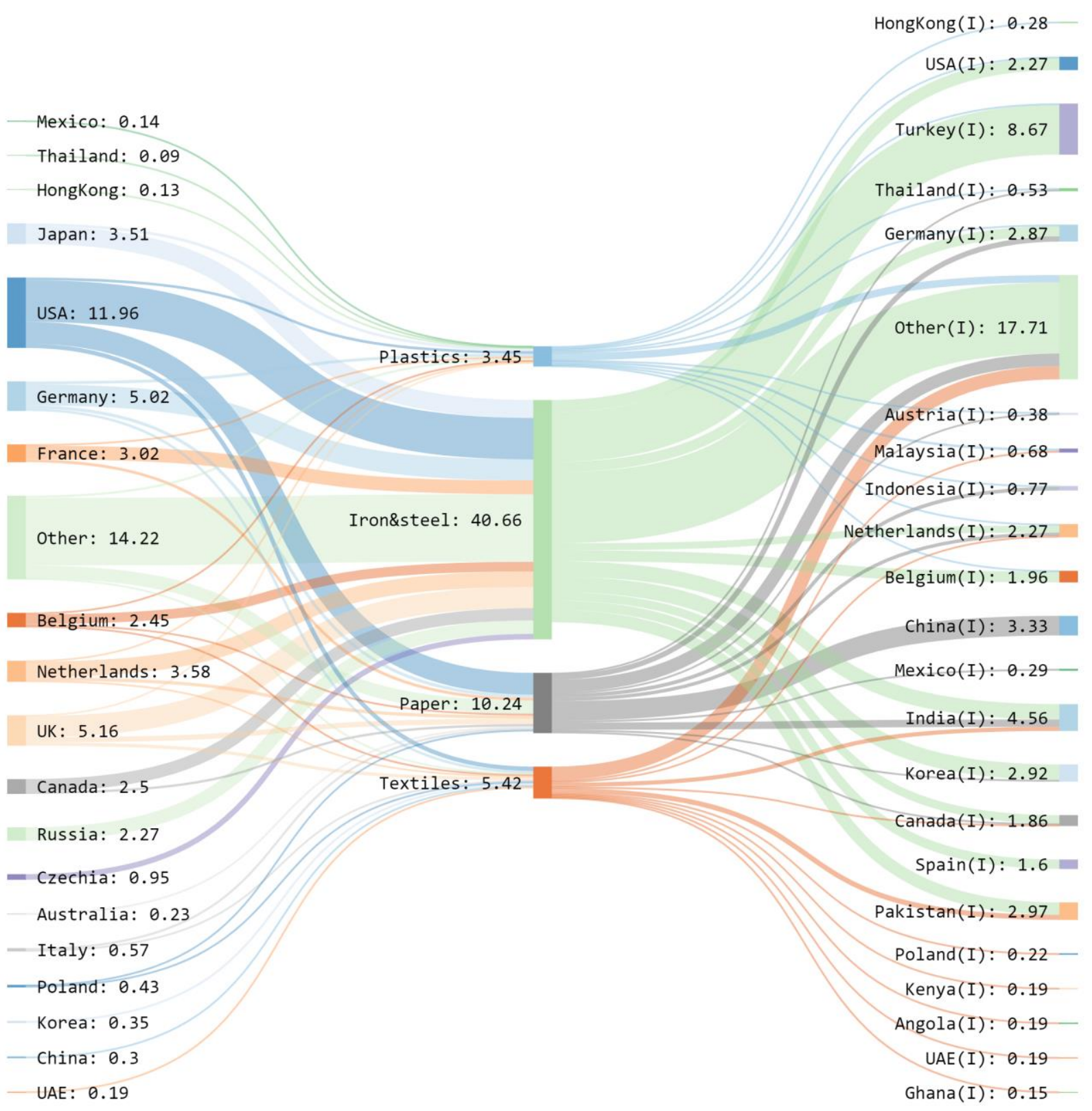

Figure 4. Sources and destinations of selected scrap materials in world trade, in declared weight (million tons, 2018). Processed on Sankeymatic, based on COMTRADE SITC v4 data (products 579, 282, 269 and 2511) 


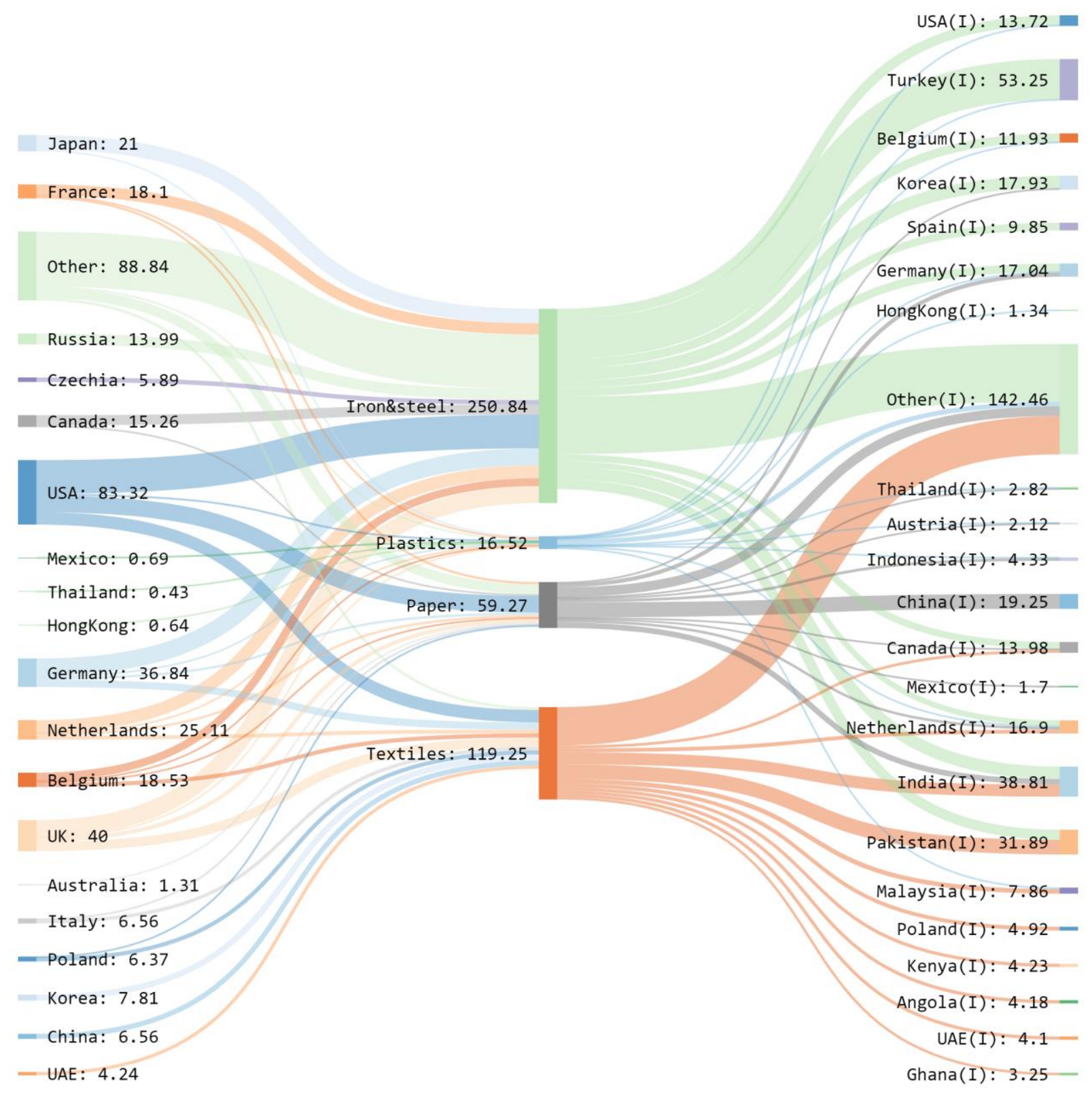

Figure 5. Sources and destinations of selected scrap materials in world trade, in estimated CO2 emissions, million tons, 2018). Processed on Sankeymatic, based on COMTRADE SITC v4 data (products 579, 282, 269 and 2511)

\section{Conclusions}

The importance of scrap materials governance was made clear through recent trade disputes and a surge in literature around the consequences of plastic pollution, which attracted significant attention to cross-border scrap material governance. At the same time, far less attention has been devoted to the environmental consequences of other scrap materials routinely traded in the world. 
This study briefly compared major export and import flows of scrap plastic, paper, ferrous metals and used textiles. The sheer size of scrap paper trade, especially trade flows originating from the United States, is noticeable. While paper is generally considered a less cumulative material, it is often used in conjunction with metallic or plastic foil, as well as paint/branding imprints which increase its environmental consequences, an issue which has received little research attention. Similarly, little understanding exists around the impacts of ferrous metals scrap trade to the environment, and in view of large trade flows in such materials, this area also warrants further research.

Used textiles trade represented a comparatively small tonnage in 2018, but their proportional value was higher. This is due to the fact that used textiles can often be readily reused without extensive reprocessing or upcycling like in the case of plastics. The estimated carbon emissions associated with used textile trade has been estimated to be 20 times more CO2 intensive than equivalent in plastics. In other words, smaller secondary markets that don't weigh or value as much can nevertheless cast a heavy shadow in terms of climate impact.

This context reinforces the importance of circular economy and governance approaches which are flexible to incorporate various types of materials, stimulating durability and recovery of resources within and across countries, in view of promoting decarbonization and pollution management considering the embodied-characteristics of materials.

\section{References}

Brooks, Amy., Wang, Shunli., Jambeck, Jenna. (2018) The Chinese import ban and its impact on global plastic waste trade. Science Advances 4, issue 6. Available at:

https://advances.sciencemag.org/content/4/6/eaat0131.short

Businesswire (2019) Global recycled plastics market estimate and forecasts. Available at: https://www.businesswire.com/news/home/20190710005287/en/Global-50.5Bn-RecycledPlastics-Market-Plastic-Type

CNBC (2019) Malaysia, following in China's footsteps, bans imports of plastic waste. Available at: https://www.cnbc.com/2019/01/25/climate-change-malaysia-following-china-bans-plasticwaste-imports.html

Dalin, Carole., Wada, Yoshihide., Kastner, Thomas,, Puma, Michael J. (2017) Groundwater depletion embedded in international food trade. Nature 543, pp 700-704. Available at:

https://www.nature.com/articles/nature21403?sf66764183=1 
Endplasticwaste (2020) Alliance to end plastic waste. Available at: https://endplasticwaste.org/ EPICENTER (2019) Recapturing the value of the world's trash. Weatherhead Center for International Affairs publications. Available at: https://epicenter.wcfia.harvard.edu/blog/recapturing-value-of-the-worlds-trash

Eriksen, Marcus., Lebreton, laurent., Carson, Henry., Thiel, Martin., Moore, Charles J., Borerro, Jose., Galgani, Francois. (Plastic Pollution in the World's Oceans: More than 5 Trillion Plastic Pieces Weighing over 250000 tons afloat at Sea.

GATT (1994) Article XX - General Exceptions. Available at: https://www.wto.org/english/res e/booksp e/gatt ai e/art20 e.pdf.

Hasanbeigi, Ali., Price, Lynn. (2015) A technical review of emerging technologies for energy and water efficiency and pollution reduction in the textile industry. Journal of Cleaner Production 95, Issue 15, pp 30-44. Available at:

https://www.sciencedirect.com/science/article/pii/S095965261500205X?casa token=xL8Z8nRI7 ZkAAAAA:Kgbgs UwbTjCOKcRPerO-

WNKYhJDb0NvFCfxFNjFief oSVjAklQy XabMW01NiVbdLIKVmJHLVZ

lacovidou, Eleni., Velis, Costas A., Purnell, Phil., Zwirner, Oliver., Brown, Andrew., Hahladakis, John., Millward-Hopkins, Joel., Williams, Paul., (2017) Metrics for optimizing the multi dimensional value of resources recovered from waste in a circular economy: A critical review. Journal of Cleaner Production 166, pp 910-938.

Ince, Bahar., Cetecioglu, Zeynep., Ince, Orhan. (2011) Chapter 11: Pollution prevention in the Pulp and Paper industries. In: Environmental Management in Practice. Available at: https://books.google.ch/books?hl=en\&lr=\&id=jGdDwAAQBAJ\&oi=fnd\&pg=PA223\&dq=paper+cardboard+pollution\&ots=2nmyjAvqHU\&sig=Bfh9kxviRmSxWxPosmB3pQd4O8\&redir esc=y\#v=onepage\&q=paper\%20cardboard\%20pollutio $\underline{\mathrm{n} \& \mathrm{f}=\mathrm{false}}$

IPCC (2018) Fifth Assessment Report. Industry chapter. Available at: https://www.ipcc.ch/site/assets/uploads/2018/02/ipcc wg3 ar5 chapter10.pdf

ISRI (2020) International Scrap Trade Database. Available at: https://www.isri.org/recyclingcommodities/international-scrap-trade-database

Katende-Magezi, Esther (2017) The impact of second hand clothes and shoes in East Africa. CUTS International. Available at: http://repository.eac.int/handle/11671/1848 Katz, Cheryl. (2019) Piling up: How China's Ban on Importing waste has stalled global recycling. Yale 360. Available at: https://e360.yale.edu/features/piling-up-how-chinas-ban-onimporting-waste-has-stalled-global-recycling 
Kissinger, Meidad., Sussmann, Cornelia., Moore, Jennie., Rees, William E. (2013) Accounting for Greenhouse Gas Emissions of Materials at the Urban Scale-Relating Existing Process Life Cycle Assessment Studies to Urban Material and Waste Composition. Low Carbon Economy 4, pp 36-44. Available at:

https://pics.uvic.ca/sites/default/files/uploads/publications/Accounting\%20for\%20GHG...Moore.p df

Krausmann, Fridolin., Gingrich, Simone., Eisenmenger, Nina., Erb, Karl-Heiz., Haberl, Helmut., Fischer-Kowalski, Marina (2009) Growth in global materials use, GDP and population during the 20th century. Ecological Economics 68, Issue 10, pp 2696-2705.

Liu, Zhe., Adams, Michelle., Walker, Tony R. ( 2018) Are exports of recyclables from developed to developing countries waste pollution transfer or part of the global circular economy?

Resources, Conservation and Recycling 136, pp 22-23.

Nikkei (2019) Philippines slams the door on worlds plastic waste. Available at:

https://asia.nikkei.com/Spotlight/Environment/Philippines-slams-the-door-on-world-s-plasticwaste

OECD (2018) Government support for primary and secondary metal production. Policy Highlights. Available at: https://www.oecd.org/environment/waste/Policy-Highlights-GovernmentSupport-for-Metal-Production.pdf

Plasticpollutioncoallition (2020) Plastic pollution coallition. Earth Island Institute. Available at: https://www.plasticpollutioncoalition.org/about-us

Pongracz, Eva. (2007) Chapter 9: The environmental impacts of packaging. In: Environmentally Conscious Materials and Chemical Processing. Available at:

https://www.researchgate.net/publication/229796182 The Environmental Impacts of Packagi

$\underline{\mathrm{ng}}$

Preston, Felix., Lehne, Johanna. (2017) A wider circle? The circular economy in developing countries. Available at:

https://www.chathamhouse.org/sites/default/files/publications/research/2017-12-05-circulareconomy-preston-lehne-final.pdf

Recycling International (2019) Growth ahead for multi-billion paper recycling sector. Available at: https://recyclinginternational.com/paper/growth-ahead-for-multi-billion-paper-recyclingsector/28930/

Rockstrom, Johan et. al. (2009) Planetary Boundaries: Exploring the Safe Operating Space for Humanity. Ecology and Society 14, N. 2. Available at: https://www.jstor.org/stable/26268316?seq=1\#metadata info tab contents 
Schreck, Maximilian., Wagner, Jeffrey. (2017) Incentivizing secondary raw material markets for sustainable waste management. Waste Management 67, pp 354-359.

SMEP (2019) Manufacturing pollution in sub Saharan Africa and South Asia. Implications for the environment, health and future work. Available at: https://www.smepprogramme.org/s/files

SMEP (2020) Manufacturing Pollution in sub-Saharan Africa and South Asia: Implications for the environment, health and future work. Available at: https://www.smepprogramme.org/s/files

Sofilic, T., Bertic, B. Simunic-Meznaric, V., Brnadic, I. (2013) Soil pollution as a result of temporary steel scrap storage at the melt shop. Ecologia Balkanica, Vol 5, Issue 1, pp 21-30. Available at: https://www.cabdirect.org/cabdirect/abstract/20143031370

Stahel, Walter (2016) The circular economy. Nature 531, issue 7595. Available at: https://www.nature.com/news/the-circular-economy-1.19594

Statista (2018) Apparel resale market value worldwide. Available at:

https://www.statista.com/statistics/826162/apparel-resale-market-value-worldwide/

Steinberger, Julia., Roberts, Timmons., Peters, Glen., Baiocchi, Giovanni. (2012) Pathways of human development and carbon emissions embodied in trade. Nature Climate Change 2, pp 81-85. Available at: https://www.nature.com/articles/nclimate1371

UNCTAD (2018) Circular Economy: The New Normal. Policy Brief No. 61. Available at: https://unctad.org/en/pages/PublicationWebflyer .aspx?publicationid=2137

Waste360 (2019) Communities turn to burning recyclables amid China Ban. Available at: https://www.waste360.com/recycling/communities-turn-burning-recyclables-amid-china-ban Wilson, David., Velis, Costas., Cheeseman, Chris. (2006) Role of informal sector recycling in waste management in developing countries. Habitat International Volume 30, Issue 4, pp 797808. Available at: https://www.sciencedirect.com/science/article/pii/S0197397505000482?casa token=M5JQHuSm24AAAAA:Xi FIAAJFxRg4qyyVpz4EfD3sCcXoYYcUR3wty8IK5vQeZX30WuqZNf4Tv5QL5 G $\underline{\text { 5RmMk40jp1E0 }}$

WTO (2017) China's import ban on solid waste. Available at:

https://www.wto.org/english/news e/news17 e/impl $030 c t 17$ e.htm 


\section{Annex 1}

Calculated prices of selected recyclables traded in 2015 and 2018, in current values. 


\begin{tabular}{lccccccccc} 
& \multicolumn{7}{c}{$\begin{array}{c}\mathbf{2 0 1 8} \\
\left(\mathbf{U S D} / \mathbf{k g}^{*}\right)\end{array}$} \\
& World & China & US & Japan & Germany & India & Brazil & Malaysia \\
\cline { 2 - 10 } Exported Plastics & 0.53 & 2.39 & $\mathrm{~N} / \mathrm{A}$ & 0.39 & 0.40 & 1.30 & 0.68 & 0.56 \\
Imported Plastics & 0.38 & 0.76 & 0.61 & 0.70 & 0.33 & 0.36 & $\mathrm{~N} / \mathrm{A}$ & 0.21 \\
Exported Textiles & 1.51 & 1.35 & $\mathrm{~N} / \mathrm{A}$ & $\mathrm{N} / \mathrm{A}$ & 0.81 & 0.96 & 3.22 & 0.80 \\
Imported Textiles & 0.75 & 0.55 & 0.87 & 2.68 & 0.66 & 0.36 & $\mathrm{~N} / \mathrm{A}$ & 0.76 \\
Exported Paper & 0.19 & 0.38 & 0.17 & 0.18 & 0.14 & 0.42 & 0.19 & $\mathrm{~N} / \mathrm{A}$ \\
Imported Paper & 0.18 & 0.25 & 0.20 & 0.26 & 0.18 & 0.21 & 0.19 & 0.20 \\
Exported Iron/steel & 0.45 & 0.15 & 0.34 & 0.42 & 0.47 & 1.30 & 0.41 & 0.49 \\
Imported iron/steel & 0.69 & 0.58 & 0.37 & 1.10 & 0.39 & 0.54 & 0.38 & 0.48 \\
\hline
\end{tabular}

* or last year available

\begin{tabular}{|c|c|c|c|c|c|c|c|}
\hline \multirow[b]{2}{*}{ World } & \multicolumn{4}{|c|}{$\begin{array}{c}2015 \\
\text { (USD/kg) }\end{array}$} & \multirow[b]{2}{*}{ India } & \multirow[b]{2}{*}{ Brazil } & \multirow[b]{2}{*}{ Malaysia } \\
\hline & China & US & Japan & Germany & & & \\
\hline 0.39 & 2.26 & 0.40 & 0.39 & 0.39 & 0.59 & 0.17 & 0.51 \\
\hline 0.48 & 0.57 & 0.60 & 1.43 & 0.36 & 0.51 & 0.45 & 0.25 \\
\hline 0.95 & 2.16 & 0.96 & 0.44 & 0.79 & 1.17 & 1.94 & 0.81 \\
\hline 0.68 & 0.52 & 0.82 & 2.21 & 0.78 & 0.33 & 0.28 & 0.66 \\
\hline 0.18 & 0.44 & 0.16 & 0.18 & 0.14 & 0.31 & 0.20 & 0.31 \\
\hline 0.18 & 0.18 & 0.15 & 0.39 & 0.16 & 0.22 & 0.22 & 0.19 \\
\hline 0.31 & 0.37 & 0.31 & 0.31 & 0.39 & 1.13 & 0.26 & 0.29 \\
\hline 0.34 & 0.51 & 0.28 & 1.24 & 0.30 & 0.44 & 0.18 & 0.29 \\
\hline
\end{tabular}

Source: Calculated by the authors based on COMTRADE, SITC v4. 